Article published in

Journal of Economic Policy Reform

doi:10.1080/17487870.2020.1778475

\title{
The 2008 Chilean Pension Reform: Household Financial Decisions and Gender Differences*
}

\author{
Alessandro Bucciol \\ Martina Manfrè \\ Gregorio Gimenez ${ }^{\dagger}$ \\ University of Verona \\ University of Verona \\ University of Zaragoza \\ alessandro.bucciol@univr.it \\ martina.manfre@univr.it \\ gregim@unizar.es
}

\begin{abstract}
We evaluate the effect of the 2008 pension reform in Chile, applying a difference-indifference estimation method to longitudinal survey data representative of the Chilean population. Our evidence suggests that those who started to receive a basic pension increased their debt more than their assets. We interpret this as an indicator of debt sustainability. The debt ratio increased significantly more for women, who may be particularly exposed to financial crises. The results raise concerns about the potential financial vulnerability of the population targeted by the reform, due to overindebtedness.
\end{abstract}

Keywords:

Chile; Pension; Financial vulnerability; Gender vulnerability;

Difference-in-difference.

This research did not receive any specific grant from funding agencies in the public, commercial, or not-for-profit sectors. Declaration of interests: none. The usual disclaimers apply.

$\dagger$ Corresponding author: Gregorio Gimenez. Postal address: University of Zaragoza, Faculty of Economics and Business, Gran Vía, 2 (50005) - Zaragoza (SPAIN). Email: gregim@unizar.es 


\section{Introduction}

Recent changes in demographic trends and increased concerns about social welfare have added urgency and purpose to pension reforms in both developed and developing countries (Barrientos, 1998). As the long-term consequences of population aging have become evident and more widely discussed, the effectiveness of social pensions in improving household welfare has received considerable attention (Samwick, 2000). Pension reforms mainly address the problem of low pension coverage without imposing an excessive burden on the public finances. However, they may also be used to redistribute wealth to specific target groups.

This is the case in Chile, a country with generally higher savings rates than-other Latin American countries (Morandè, 1998), - albeit with huge inequalities (Engel et al., 1999). With the 2008 reform of the pension system, the Chilean government sought to improve the adequacy of pension pay-outs to specific groups of the population, notably the poorest households with at least one member older than 65. Since 2008, these households have been eligible to receive more income from pensions and use it for consumption, savings and investments. The reform aimed to strengthen the social safety net, foster solidarity and improve gender equality (Rofman et al., 2008). According to Borzutzky (2019), the reform expanded coverage and, consequently, improved social equity. Previous research also indicates that it increased individual spending, improved self-reported health (Berhman et al., 2011) and reduced dependence on the labor market (Attanasio et al., 2011; Encina, 2013). However, the consequences of the reform in terms of financial inclusion has not been investigated, although access to finance is a critical factor for boosting well being and equality.

Like in the case of other governments in Latin America, in the past two decades, the government of Chile has undergone important transformations in the way it adopts public service provision. The reforms brought about have strived to incorporate a citizen perspective, in a very complex context - characterized by globalization, economic and political instability and rising inequality. The new outlook focuses on producing more public value with greater efficiency, putting the interests of the "consumers" of public services at the center of the decision-making process (OCDE/CAF/CEPAL, 2018). Within the broader reform framework, a citizen demand has been emerging in Chile for the government to analyse the consequences of its policies from a gender perspective. ${ }^{1}$

\footnotetext{
${ }^{1}$ Result of this interest is the creation of the Ministerio de la Mujer y la Equidad de Género of Chile, in 2015, which has among its functions "to promote, coordinate and evaluate the incorporation of the gender
} 
The goal is to make visible and correct gender imbalances in decision-making and to ensure that the services provided are equally accessible to all citizens and meet the needs of women and men alike.

The aim of this paper is to evaluate the effects of the 2008 Chilean pension reform on financial outcomes. The Chilean pension reform could affect citizens' behavior and well-being, two key elements in the debates on public service provision and its reform. In particular, we wanted to learn how the targeted population reacted to the increase in the income stream via the reform, and how behavior changed in relation to various financial instruments. Did those affected by the reform increase their participation in debt and asset markets? Did participation in debt and asset markets change at a similar rate? Our analysis pays special attention to women. Chilean women have traditionally encountered more difficulties than men in accessing the labor market (e.g., Ramirez and Ruben, 2015) and, as a consequence, they have had more limited access to pensions. This led us to investigate whether the effects of the pension reform were different for men and women, after controlling for other observable characteristics. Did decisions affect women and men differently?

Chile is a special case for two reasons. The first is economic: it has undergone rapid economic growth with many problems of inequality, partly because of its liberal economic policies in recent decades (including tax, labor and pension reforms), quite different from other Latin American countries (López and Miller, 2008). The second reason is technical: the effect of policy reforms on financial inclusion in Latin American countries has not been widely investigated, mainly due to the lack of data. Few household surveys in developing countries collect information on debt and assets ownership (Deere and Catanzarite, 2017), but a large representative Chilean survey, Encuesta de Protección Social (EPS), overcomes this limitation. The survey is unique in Latin America, both due to its methodological rigor and the amount of information on wealth and financial instruments included.

Our results show a significant impact of the Basic Solidarity Pension (Pensión Básica Solidaria, henceforth PBS) on the access to debt, more than access to assets. The effect of the policy may be due to the characteristics of the targeted population, comprising poor households with at least one member older than 65 . The increase in the income stream provided by the reform may not be large enough to stimulate their

perspective in the policies and plans of the various ministries and services at the national and regional levels". 
participation in financial markets; in contrast, it may be that the recipients used the PBS as a collateral for acquiring more debt, rather than using it as a way to finance new investments. Women increased their debt and debt ratio significantly more than men.

The remainder of the paper is organized as follows. Section 2 provides an overview of the existing literature and describes the Chilean pension system and the policy reform. Section 3 presents the data and some summary statistics. Section 4 comments on our findings and Section 5 concludes.

\section{Background}

\subsection{Literature review: previous reforms in Latin American countries}

Previous studies on old-age poverty show low levels of pension coverage in most Latin American countries. However, social security has recently become a central issue in the policy debate (Rofman and Oliveri, 2012).

Over the last three decades many countries in Latin America have carried out structural reforms to privatize their pension schemes, with the primary aim of reducing old-age poverty. Following the example of Chile, which pioneered pension reform in 1981, other countries embraced reforms during the 1990s: Peru (1993), Colombia and Argentina (1994), Uruguay (1996), Bolivia and Mexico (1997), El Salvador (1998).

The introduction of privatized pension systems in Latin American countries was expected to increase pensions for future beneficiaries and to accelerate savings, with positive consequences on economic growth (World Bank, 1994). However, some claims about the positive effects of such reforms on social welfare have been disproved by the evidence (Mesa-Lago, 2002). For example, Altiparmakov and Nedeljkovic (2018) show a positive, although limited, impact of pension privatization on aggregate savings rates, but find no evidence of higher economic growth. Other authors highlight the existence of a trade-off between the efficiency of a reform in limiting pension debt and its social costs in terms of welfare reduction: as pension privatization is costly to implement, it may exacerbate financial pressures in the short-to-medium term (Brooks, 2007; Olivera, 2016). Concerns were also raised about the transition process, as it may introduce financial risks and intergenerational inequalities via the "double burden" problem. Indeed, during the transition period, some individuals have to pay current retirees' pensions, in addition to their own (Arza, 2008).

Another body of research indicates that governments must look for other alternatives to reduce old-age poverty. For example, cash transfer programs focused on 
the elderly may be more effective than structural pension reforms in reducing poverty (Barrientos and Lloyd-Sherlock, 2003; Barrientos, 2006; Case and Deaton, 1998). Indeed, some non-contributory pension schemes have become popular in Latin America (Olivera and Zuluaga, 2014).

Among Latin American countries, only Bolivia provided, from 1997, a universal basic pension to all residents above a certain age regardless of income or assets, called BONOSOL. In the 1990s, following the mandate in the 1988 Constitution to provide pensions to the elderly in rural areas, Brazil began to offer cash transfers to elderly individuals who had worked in the informal sector, agriculture, fishing or similar activities. In Mexico, the federal government introduced a social security program in 2007, known as "70 y Más“, providing a cash transfer to rural adults over the age of 70 . In the mid-2000s, Argentina adopted the "Moratorium" program for the inclusion of the self-employed in retirement age without sufficient years of contribution. Since 1974 Costa Rica has carried out an expensive social program to assist the poor over the age of 65. Brooks (2007) indicates that the costs of cash transfer programs for the elderly in Latin America are low, typically less than 1 percent of GDP, and argues that refocusing pension reform on poverty reduction would contribute to a much-needed reorientation of social policy in Latin America.

\subsection{The history of the Chilean Pension System}

Chile is one of the Latin American countries that have reformed their pension systems more radically over the years. Until 1981, the Chilean pension system was of the defined benefit type, financed on a pay-as-you-go basis. Subsequently, it was reformed under the Pinochet regime, when the labor minister Piñera argued that the defined benefit scheme was financially unsustainable in the long term.

In May 1981, the pension system was changed into a fully-funded, defined contribution system, in which working people were required to allocate $10 \%$ of their income from employment to individual pension accounts. For the following 30 years, individual pension accounts were managed by private-sector providers, so-called Pension Fund Managers (AFPs, Administradoras de Fondos de Pensiones). Working people were required to contribute for at least 20 years in order to be eligible for a guaranteed minimum pension (Berhman et al., 2011).

The new private system was expected to oblige private savings, funded by wages, thus improving efficiency and reducing administrative costs (Mesa-Lago and Bertranou, 
2016). However, this system turned out to be unable to meet the pension needs of a country like Chile, with many self-employed and informal workers (López García, 2015). The new system was also criticized for preventing the state from protecting pensions; it made workers more vulnerable due to the uncertainty of the individual pension and the decline in bargaining power. Social inequality remained or actually increased because periods of unemployment penalized pension entitlements; the structural reform also aggravated gender inequalities (Mesa-Lago and Bertranou, 2016).

\subsection{Chile's 2008 pension reform}

Poor coverage, as well as low pension benefits and high administrative costs, intensified the need for pension reform to supplement the deficiencies of the private pension system. Hence, in 2008 Chile pioneered a "re-reform" to extend coverage to specific subgroups of the population, notably the poorest and the elderly, raising pension pay-outs and increasing gender equality (Mesa-Lago, 2014). The 2008 reform was designed to improve solidarity in the compulsory and voluntary pillars of the old pension scheme by introducing two new components (Encina, 2013): the PBS and a top-up pension (Aporte Previsional Solidario).

The PBS kicked off in July 2008. It provides a basic pension to all households i) with at least one member over 65 , ii) in the $40 \%$ less affluent portion of the population ${ }^{2}$ and iii) that do not satisfy minimum contributions requirements. ${ }^{3}$ A poverty score called the "Ficha de Proteccion Social" (from now on, FPS) is used to determine the less affluent population; a household is considered eligible for PBS when the FPS is 12,666 points or lower.

The PBS provided eligible households with about USD 105 monthly, reaching USD 156 in July 2011 (Encina, 2013). Benefits are financed by the government through a Solidarity Fund and, in part, by local municipalities and Pension Fund Managers (Berhman et al., 2011). The additional component introduced in 2008 was a welfare pension aimed at sustaining consumption for those with incomplete contributions histories in the old pension system (Attanasio et al., 2011). Part of the existing literature investigates the effect of receiving additional pension benefits, such as PBS, on consumption. However, Berhman et al. (2011) find little evidence of crowding-out

2 The subsidy was gradually extended, reaching the poorest $60 \%$ of the elderly population by the end of 2011, as determined by a poverty score called the "Ficha de Proteccion Social".

3 Entitlement to the benefit includes at least 20 years residency and residence in the country for at least four of the five years prior to the reform (OECD, 2017). 
private transfers: whilst individuals receiving PBS declare an improvement in selfreported health, the effects on cigarette consumption, alcohol intake and the purchase of consumer durables are small and not statistically significant. Moreover, after implementation of the reform, they find a significant reduction in hours worked per week among individuals receiving PBS. Similarly, Encina (2013) provides evidence of higher withdrawals from the labor market among individuals receiving PBS, with longer periods of inactivity and lower contribution rates. Whilst acknowledging the positive effect of additional pension benefits on self-financed pension wealth, Attanasio et al. (2011) record a reduction in formal labor market participation after the reform, significantly higher for women. More recently, Wong (2016) finds an increased incentive to leave the formal sector and to evade taxes after the reform, where people expected to face an increase in their implicit marginal tax rate. Despite the growing interest in the effect of the 2008 Chilean pension reform on the economic behavior of consumers, relatively little is known about the impact of additional pension benefits, such as PBS, on financial decisions. This research contributes to filling this gap.

\section{Data Overview}

\subsection{Encuesta de Protección Social (EPS)}

We use Chilean data from the Encuesta de Proteccion Social (henceforth, EPS). The EPS is the largest longitudinal survey in Chile, with a sample of around 16,000 respondents from all regions in the country. Since 2002 and up to the time of writing, five waves have been carried out. Data are collected by the Microdata Center of the Universidad de Chile, in collaboration with the Chilean Subsecretaría de Previsión Social under the guidance of a research team from the University of Pennsylvania. The EPS gathers information on individuals over the age of 15 and representative of the Chilean population. In addition to socio-demographic information, it includes data about employment and social security history, family composition, health, wealth and financial instruments.

\subsection{Sample selection}

We focus on the two EPS waves collected immediately before and after the 2008 pension system reform: the 2006 and 2009 waves. The 2009 wave allows us to study the 
short-term effects of the policy reform. ${ }^{4}$ Our data include one respondent per household, and we restrict our attention to individuals aged less than 90 to avoid outliers in the data. We also consider respondents who completed the survey in both years 2006 and 2009 , to ensure that differences over time are representative of changes in responses rather than changes in sample composition (Berhman et al., 2011).

Our sample comprised two groups (treatment and control) with similar characteristics. The treatment group includes individuals who received the pension benefit PBS in 2009; following Encina (2013), the control group includes individuals who did not receive PBS in 2009, but could have been eligible based on our information. In particular, we consider respondents older than 65 at the time of the implementation of the reform, and with an FPS score of 12,666 points or lower (Behrman et al., 2011). ${ }^{5}$ This second requirement ensures that the treatment and control groups have a similar level of economic wellbeing. Any further reasons for the receipt of PBS are considered exogenous to this study.

The FPS score is an index measured at the household level which reflects the ability to generate income based on economic needs (Herrera et al., 2010). The higher the score, the better the economic condition of the household. The formula used to calculate the index is not publicly available, but it is known that it is based on a wide set of socioeconomic characteristics, such as household size and composition, income, health status and years of education (Attanasio et al., 2011).

In 2009, the survey asked individuals whether they filled in the FPS, and if so to report their FPS score. However, only $12 \%$ of the respondents reported the score. In our analysis, we follow the approach proposed by Wong (2016) to predict the FPS score as a function of the socioeconomic components listed above. We then estimate the following equation based on 2009 data for those who reported their FPS score:

4 Unfortunately, we were not able to use EPS waves after 2009. In particular, the Subsecretaria de Previsión Social describes the 2012 wave as an "incomplete product" and does not recommend its use for statistical inference purposes, due to the level of error this may entail. See www.previsionsocial.gob.cl/sps/biblioteca/encuesta-de-proteccion-social/bases-de-datos-eps/. Data prior to 2006 are reliable, but include information only on a subset of assets, liabilities and income sources in our sample. We use 2004 data in some robustness checks.

5 As robustness checks, in our analysis we also consider two alternative control groups comprising individuals who do not meet the requirements for elegibility, i.e., individuals in the age range 60-65 and individuals who did not fill in the FPS. The control group may not have received PBS because households did not apply (probably unaware of the opportunity) or they were already receiving other pensions from the government. We do not believe any households failed to apply because uninterested in accessing assets and debt markets. The PBS provides a monetary incentive, no matter how it is used. 


$$
\begin{gathered}
\text { FPS }_{i}=\beta_{0}+\beta_{1} \text { Age }_{i}+\beta_{2} \text { Household size }_{i}+\beta_{3} \text { Healt }_{i} \\
+\beta_{4} \text { Income }_{i}+\beta_{5} \text { Education }_{i}+\varepsilon_{i}
\end{gathered}
$$

where $F P S_{i}$ is the predicted vulnerability indicator of household $i$ after implementation of the reform. Regression results, given in supplementary material accompanying this article (Table A.1), are based on a tobit model to acknowledge that the dependent variable may not be negative. We then used predictions from the above equation to associate each individual with a 2009 FPS score. The predicted FPS score (in our dataset: average 7,099.17, standard deviation 629.05) is used to determine eligibility for the new pension benefits, i.e., following the official rules, those who report a FPS score of 12,666 points or lower (in our dataset: 86.34 percent of the households) are considered eligible.

Figure 1. Distribution of FPS in the treatment and control groups

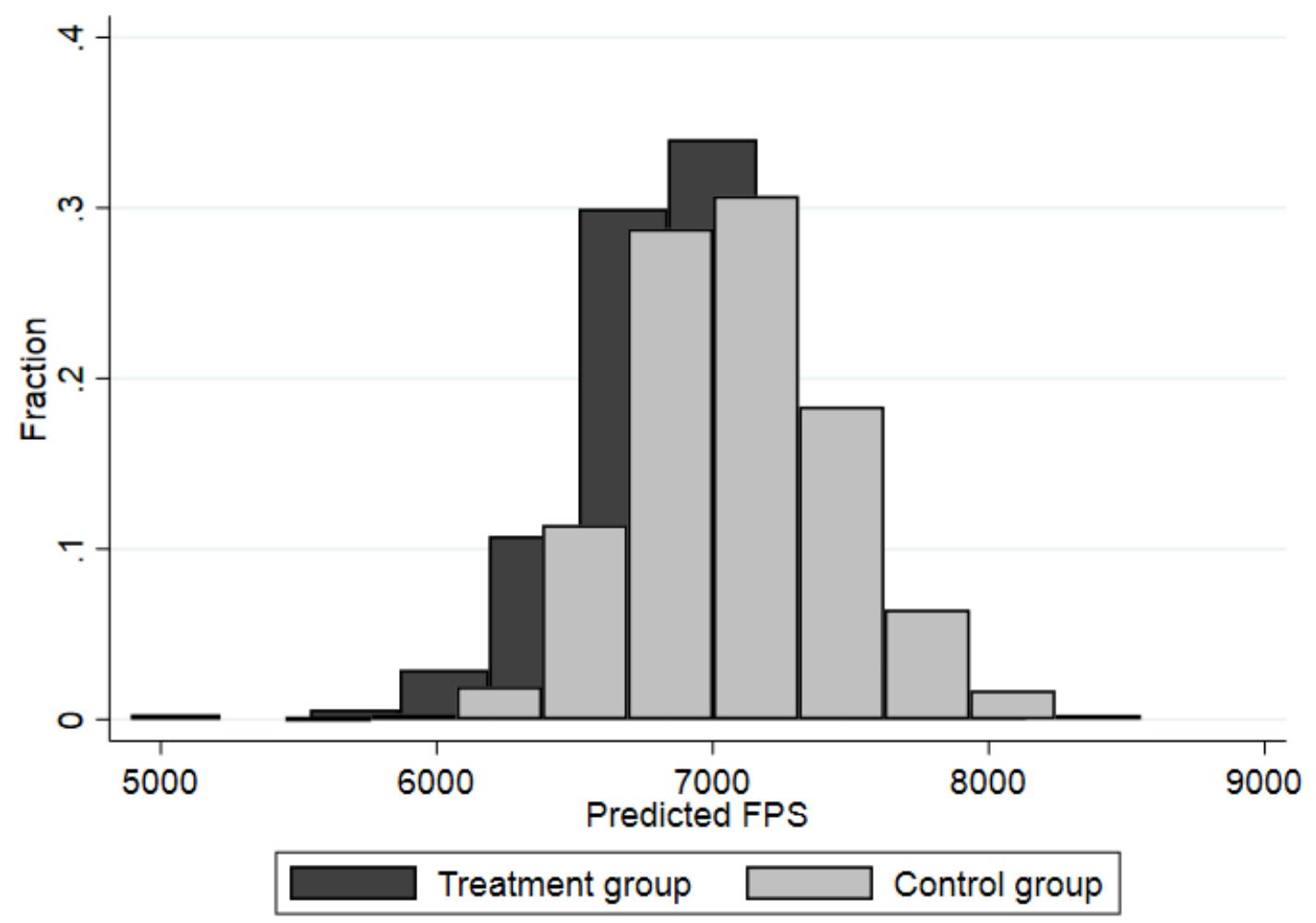

As a result of this sample selection, our final benchmark sample consists of 4,316 observations on 2,158 individuals, with 688 observations $(15.94 \%)$ in the treatment group. Figure 1 plots the distribution of FPS in our sample, separately for the treatment 
and control groups. The two distributions are very similar, although the FPS score is on average slightly lower in the treatment group $(6,871.95$ as opposed to $7,087.35)$.

\subsection{Key variables}

Table 1 provides descriptive statistics of the variables used in our research, ${ }^{6}$, divided into outcome and explanatory variables.

Our outcome variables concern holdings (extensive margin) and accumulation (intensive margin) of debts and financial assets. Regarding debt, we consider such instruments as bank lines of credit, credit cards, store credit cards, consumer credits and other forms of financial debt (i.e., student loans, social or private debts). The variable Debt (extensive margin) is a dummy equal to one if the respondent holds at least one of the above-mentioned instruments, and zero otherwise, while the variable Debt amount (intensive margin) represents the total amount in US dollars for a given debt instrument.

Regarding assets, we consider homebuyer savings accounts, voluntary pension savings, savings accounts, time deposits, mutual funds, bonds and stocks. The variable Assets (extensive margin) is a dummy equal to one if the respondent holds at least one of these instruments, and zero otherwise, while the variable Assets amount (intensive margin) represents the total amount in US dollars held in such assets.

In our sample, about 34\% report possession of at least one debt instrument, whilst financial assets were less widespread (15\%). The average amounts of debt and assets are about USD 403 and 829, respectively.

We consider two further outcome variables, intended to compare assets and debts. The variable More debt is a dummy equal to one if the amount of debt held by the household is larger than the corresponding amount of assets. Finally, the variable Debt ratio is the ratio between debt and assets.

Concerning the explanatory variables, the variable Treatment is a dummy equal to one if the individual in 2009 received PBS, and zero otherwise, while the variable After is a dummy equal to one if the observation refers to the period after the implementation of the reform (i.e., in 2009), and zero otherwise.

The remaining variables are socio-demographic controls. The average age in our sample is 72 , slightly more respondents are women (51\%) and more than a half of the sample lives with a partner (59\%). As regards education levels, only a small percentage

6 Monetary values reflect 2009 prices adjusted by the consumer price index (source: https://inflationdata.com) and converted into US dollars (source: https://www.investing.com). 
of individuals (5\%) had high education, i.e., a high school diploma or a higher degree. In our sample, $22 \%$ of respondents had worked in the previous three years and the average annual income was about 7,000 US dollars. Slightly more than one third of respondents (36\%) said they were in good health and the vast majority of individuals $(85 \%)$ own their homes. 
Table 1. Summary statistics before the reform (wave 2006); 2,158 observations

\begin{tabular}{lcccc}
\hline Variable & Mean & Std.Dev. & Min & Max \\
\hline & & & & \\
Outcome variables & & & 0 & 1 \\
Debt & 0.337 & 0.473 & 0 & 27.976 \\
Debt amount (x1000 USD) & 0.403 & 2.223 & 0 & 1 \\
Assets & 0.148 & 0.355 & 0 & 399.801 \\
Assents amount (x1000 USD) & 0.829 & 10.848 & 0 & 1 \\
More debt & 0.226 & 0.418 & 0 & 47976.18 \\
Debt ratio & 290.530 & 0.418 & & \\
& & & 0 & 1 \\
Explanatory variables & & & 63 & 90 \\
Treatment & 0.159 & 0.366 & 0 & 1 \\
Age & 71.506 & 6.053 & 0 & 1 \\
Female & 0.513 & 0.500 & 0 & 1 \\
If partner & 0.585 & 0.493 & 0 & 1 \\
Higher education & 0.045 & 0.208 & 0 & 399.810 \\
Worked in the past & 0.215 & 0.411 & 0 & 1 \\
Income (x1000 USD) & 7.350 & 38.999 & 0 & 1 \\
Good health & 0.359 & 0.480 & & \\
Home owner & 0.851 & 0.356 & & \\
& & & & \\
\hline
\end{tabular}

The research questions that we aim to respond are: i) Does PBS affect the access to the credit and debt market? ii) Does PBS favor access to the credit market more than to the debt market, or vice versa? iii) Does PBS favor access to the market by women more than men?

\section{Econometric analysis}

\subsection{Identification strategy}

We study the impact of the 2008 pension reform by using a longitudinal differencein-difference (DiD) identification strategy. Specifically, we exploit differences in the receipt of PBS to compare changes in financial outcomes for households affected by the reform in the treatment group and households in a comparable control group, before and after implementation of the reform. Both groups comprise households eligible for PBS; the difference between them is considered exogenous to our analysis, as households in the control group did not receive PBS either because they were unaware of it or because they were already receiving other government pensions.

We estimate the following regression:

$$
y_{i t}=\beta_{0}+\beta_{1} \text { Treatment }_{i t}+\beta_{2} \text { After }_{i t}
$$




$$
+\beta_{3} \text { Treatment }_{i t} * \text { After }_{i t}+X_{i t}^{\prime} \beta_{4}+\varepsilon_{i t}
$$

where $y_{i t}$ is one of the dependent variables of interest representing the financial behavior of respondent $i$ at time $t$ (extensive and intensive margin of debt and financial assets, and debt-asset comparison), Treatment $_{i t}$ is the treatment indicator, After At $_{\text {it }}$ indicates the post-treatment period, and the vector $X_{i t}^{\prime}$ represents control variables including socio-demographic information provided by the respondent, such as age, gender, education, marital status, occupation, income, health and home ownership. Finally, $\varepsilon_{i t}$ is the error term.

In our DiD analysis, the parameter of interest is the coefficient $\beta_{3}$ on the interaction term between the treatment indicator and the post-treatment period, which represents the impact of PBS on the financial behavior of poor households after the reform. This approach enables the effect of PBS on the treatment group to be measured, net of any other disturbing effect that may have arisen in the meantime (impacting on both treatment and control groups).

The DiD approach assumes parallel trends over time between treatment and control groups. Unfortunately the time observations are insufficient to carry out this check properly. However, we find some evidence in this direction from a DiD regression comparing waves in 2004 and 2006 for all our dependent variables; ${ }^{7}$ in this analysis, we find no evidence of a significant difference in the time trend of treatment and control groups (see supplementary material accompanying this article, Table A.2).

In principle, one could identify the causal impact of PBS on individuals' financial decisions in a Regression Discontinuity Design (RDD) framework, where the discontinuity is set around the FPS threshold for PBS eligibility.

However, estimating the impact by this approach may be misleading. Indeed, given the existence of serious distortions in data for FPS (Herrera et al., 2010), there may have been some manipulation of FPS scores by households to alter their priority in the eligibility for social benefits. As one of the prerequisites of the RDD approach is that assignment to treatment cannot be manipulated, our benchmark analysis relies on the

7 A problem here is that the questionnaire changed in the two waves, and for year 2004 we have information on a more limited set of income components. Specifically, we do not have information on means-tested family subsidies, water, unemployment and solidarity subsidies that in 2006 accounted for about $20 \%$ of median income. The DiD regression thus defines income based on the information available in both waves (earnings for paid work, pensions, food alimonies, donations, helps from relatives and non-relatives). 
DiD approach to estimate the causal effect of the pension reform on the outcomes of interest.

As an alternative, one could resort to fixed-effect longitudinal estimation. However, the availability of only two observations per household to a large extent limits intrahousehold variability and the suitability of this methodology in this context.

\subsection{General results}

Table 2 shows the average marginal effects obtained with the models where the dependent variables indicate holdings (extensive margin) or amounts (intensive margin) of debts and assets. We use probit models for holdings, which are binary indicators, and OLS models for amounts, which are continuous variables. We first concentrate on debt (Columns 1 and 2) and we find similar evidence for the extensive and intensive margins, with the likelihood of holdings and the amount increasing with a partner, if the respondent is younger, has worked in the past or has higher education. The treatment group is $16.9 \%$ less likely to hold debt positions (Column 1), and on average has a debt $86.3 \%$ lower than the control group (Column 2). We see a small but significant effect of the policy reform in the holding of debt, which increases by $6 \%$ in the treatment group after the introduction of PBS. Moreover, the amount of debt increased by $31 \%$ among those who have been reached by the reform. 
Table 2. Regression output: debt and assets (average marginal effects)

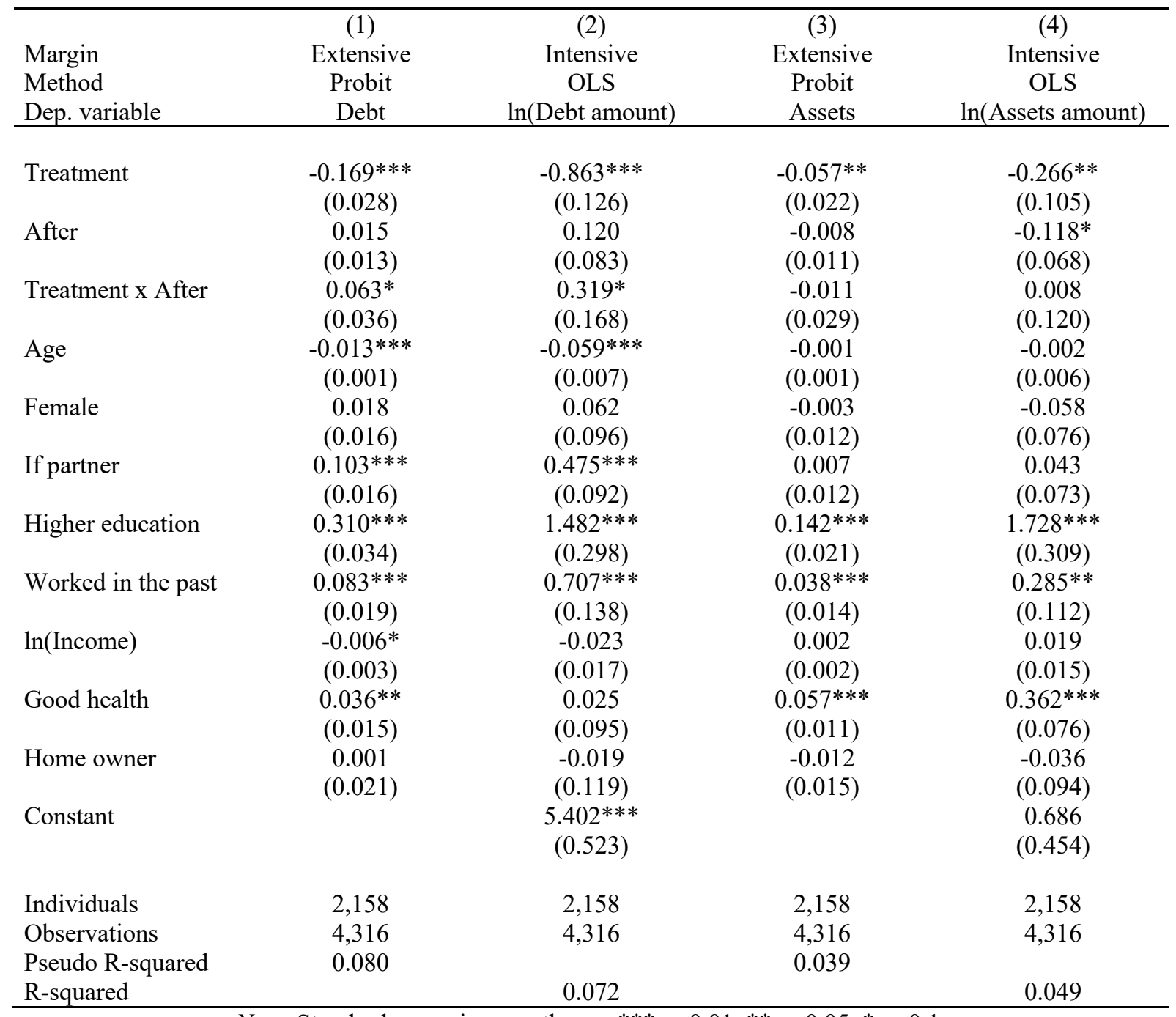

Note: Standard errors in parentheses; *** $\mathrm{p}<0.01,{ }^{* *} \mathrm{p}<0.05,{ }^{*} \mathrm{p}<0.1$.

Regarding assets (Columns 3 and 4), the likelihood of holdings and the amount increased for people with a higher education, for those who had worked or were in good health. The treatment group is $5.7 \%$ less likely to have any assets (Column 3 ), and on average has assets $26.6 \%$ lower than the control group (Column 4). The amount of assets generally fell in 2009 (by $11.8 \%$, Column 4). However, our findings show that asset market participation was not significantly affected by the policy reform. Indeed, we find no significant change in holdings and the amount of assets after the introduction of PBS. This evidence is in line with findings in Cerda (2008), who used EPS data to study a previous pension reform in Chile.

Overall, this evidence suggests that the PBS did not alter access to asset positions, but it had an impact on the probability of holding debt and on the amount. It may be that 
some people used the PBS as collateral for acquiring more debt, rather than using it as a way to finance new investments.

The analysis carried out so far evaluates the effect of the policy reform by looking separately at holdings and the amounts of debt and assets. Knowing the existence of an underlying relationship between debt and asset size, we now take a different approach to assess the impact of PBS on the financial behavior of households. We consider as dependent variable the household debt-to-assets ratio, which represents total outstanding household debt divided by total assets. ${ }^{8}$ We compare the amount of debt with the amount of assets to obtain an indicator of household debt sustainability. Indeed, the higher the debt-to-asset ratio, the higher the level of household leverage, and the weaker the financial position. We carry out the regression with output shown in Table 3. Column 1 measures the likelihood that debt exceeds assets, while Column 2 takes as a dependent variable the ratio between debt and assets. A probit model is used in Column 1 and an OLS model in Column 2 in line with the nature of the dependent variable (binary in Column 1 and continuous in Column 2). Both analyses show that, with PBS, the treatment group has relatively more debt: the probability of having more debt than assets increases by $6 \%$ (Column 1 , although the coefficient is significant at $10 \%$ only), and the debt-to-asset ratio is $33.1 \%$ higher (Column 2).

8 Following the OECD definition, available at (accessed June 12 2019):

https://www.oecd.org/sdd/na/statisticalinsightswhatdoeshouseholddebtsayaboutfinancialresilience.htm 
Table 3. Regression output: debt and assets comparison (average marginal effects)

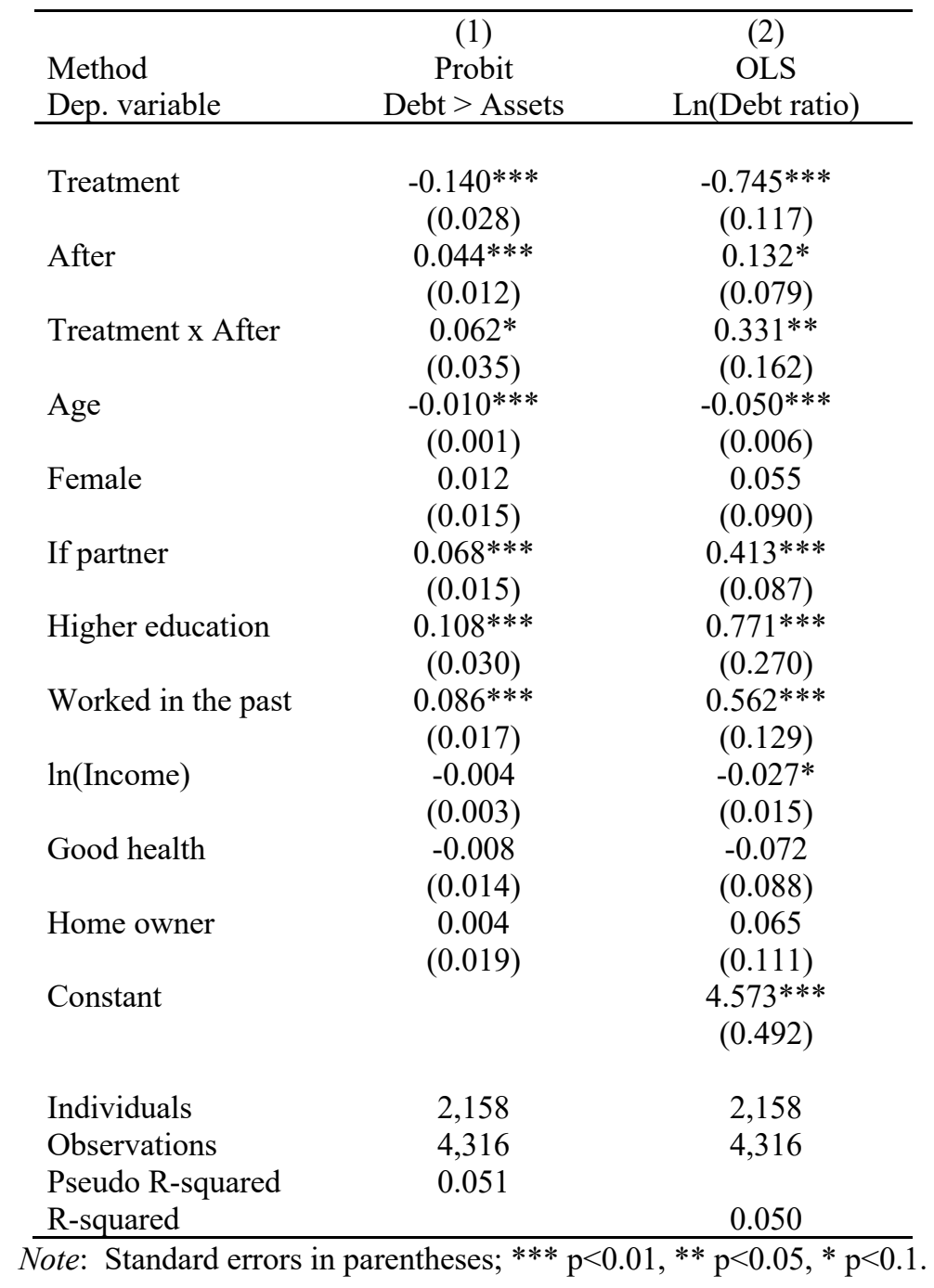

All in all, our findings indicate that the introduction of PBS stimulates the accumulation of debt more than the accumulation of assets.

We perform several tests to check the robustness of this result. The estimations can be found in the supplementary material that accompanies this article (Tables A.3 to A.5). As first robustness check, we run two "fake" experiments to see if our findings are driven by chance. One distinguishes between treatment and control groups based on one observed demographic variable: being single or having a partner. Another considers the sample years 2004 and 2006 and we artificially set the year in which the policy took place at 2005, although the treatment group remains the sub-sample of households who eventually received PBS. As the second robustness check, we use an alternative way to account for FPS by means of a principal component analysis, taking into account the same explanatory variables considered in Equation (1). Finally, we carry out the 
analysis using alternative definitions for the control group: households in the age range 60-65, or households that did not fill in the FPS (and would probably get high scores). ${ }^{9}$ The robustness checks are in line with the outcome of our benchmark analysis.

\subsection{Gender differences}

Like most other components of social protection systems, pension reforms can have a significant impact on gender equality and examining this may give a fuller view of the effectiveness of the policy (Arza, 2012). Chilean women have traditionally had less access to credit and assets than men, due partly to lower employment rates than in developed countries (e.g., Ramírez and Ruben, 2015). This has important implications in terms of dependence and economic and social well-being. Hence, gender analysis of the consequences of the Chilean pension reform on debt and assets accumulation is of great interest. Tables 2 and 3 show no significant gender effects. However, the coefficients of the gender variable were obtained net of differences in terms of sociodemographic characteristics.

In our sample females are less frequently highly educated (3.70\% against $5.43 \%)$ and on average have lower incomes (USD 7,253 against 7,452). Moreover, they are less likely to live with a partner, to work and be in good health. Table 4 shows the average amount of debt and assets by gender, before and after the pension reform. Unlike our previous analyses, this time the gender comparison does not control for differences in income or other characteristics. We see that women who received the PBS had the largest increase in the amount of debt among all groups (138\%), and the largest decrease in the amount of assets $(-81 \%)$. This led to a sizable increase in their debt ratio, the largest of all groups. The financial behavior of men taking advantage of the PBS was very different; they reduced their amount of debt and assets by $57 \%$ and $20 \%$, respectively.

9 The general aim of the vulnerable or poor filling in the FPS is to gain access to subsidies and benefits from the government (Herrera et al., 2010). We assume that those who did not fill in the FPS are more affluent and anticipate high FPS scores, excluding them from the benefits. 
Table 4. Average amount of debt and assets by gender. Constant 2009 USD

\begin{tabular}{|c|c|c|c|c|c|c|c|c|c|c|c|c|}
\hline & \multicolumn{6}{|c|}{ Control group } & \multicolumn{6}{|c|}{ Treatment group } \\
\hline & \multicolumn{2}{|c|}{$\begin{array}{c}\text { Amount of } \\
\text { debt in }\end{array}$} & \multirow[b]{2}{*}{$\Delta$ debt } & \multicolumn{2}{|c|}{$\begin{array}{c}\text { Amount of } \\
\text { assets in }\end{array}$} & \multirow[b]{2}{*}{$\Delta$ assets } & \multicolumn{2}{|c|}{$\begin{array}{c}\text { Amount of } \\
\text { debt in }\end{array}$} & \multirow[b]{2}{*}{$\Delta$ debt } & \multicolumn{2}{|c|}{$\begin{array}{c}\text { Amount of } \\
\text { assets in }\end{array}$} & \multirow[b]{2}{*}{$\Delta$ assets } \\
\hline & 2006 & 2009 & & 2006 & 2009 & & 2006 & 2009 & & 2006 & 2009 & \\
\hline Men & 585 & 981 & $68 \%$ & 1,381 & 902 & $-35 \%$ & 134 & 58 & $-57 \%$ & 64 & 51 & $-20 \%$ \\
\hline Women & 331 & 357 & $8 \%$ & 514 & 383 & $-25 \%$ & 71 & 169 & $138 \%$ & 160 & 30 & $-81 \%$ \\
\hline
\end{tabular}

The gender differences we observe in debt and assets may be a consequence of the pension reform; however, it could also be due to differences in the other predictors of the model. To compare to what extent the differences in the financial behavior of men and women can be attributed to the reform, we estimate the predicted mean of holding probabilities and the amounts of debt and assets after controlling for the rest of the predictors. Figure 2 shows the results. All those individuals who received the PBS increased both their debt and assets more than those who did not receive the benefit (the only exception was the likelihood of women holding assets).

Figure 2. Adjusted linear predictions of debt and assets positions

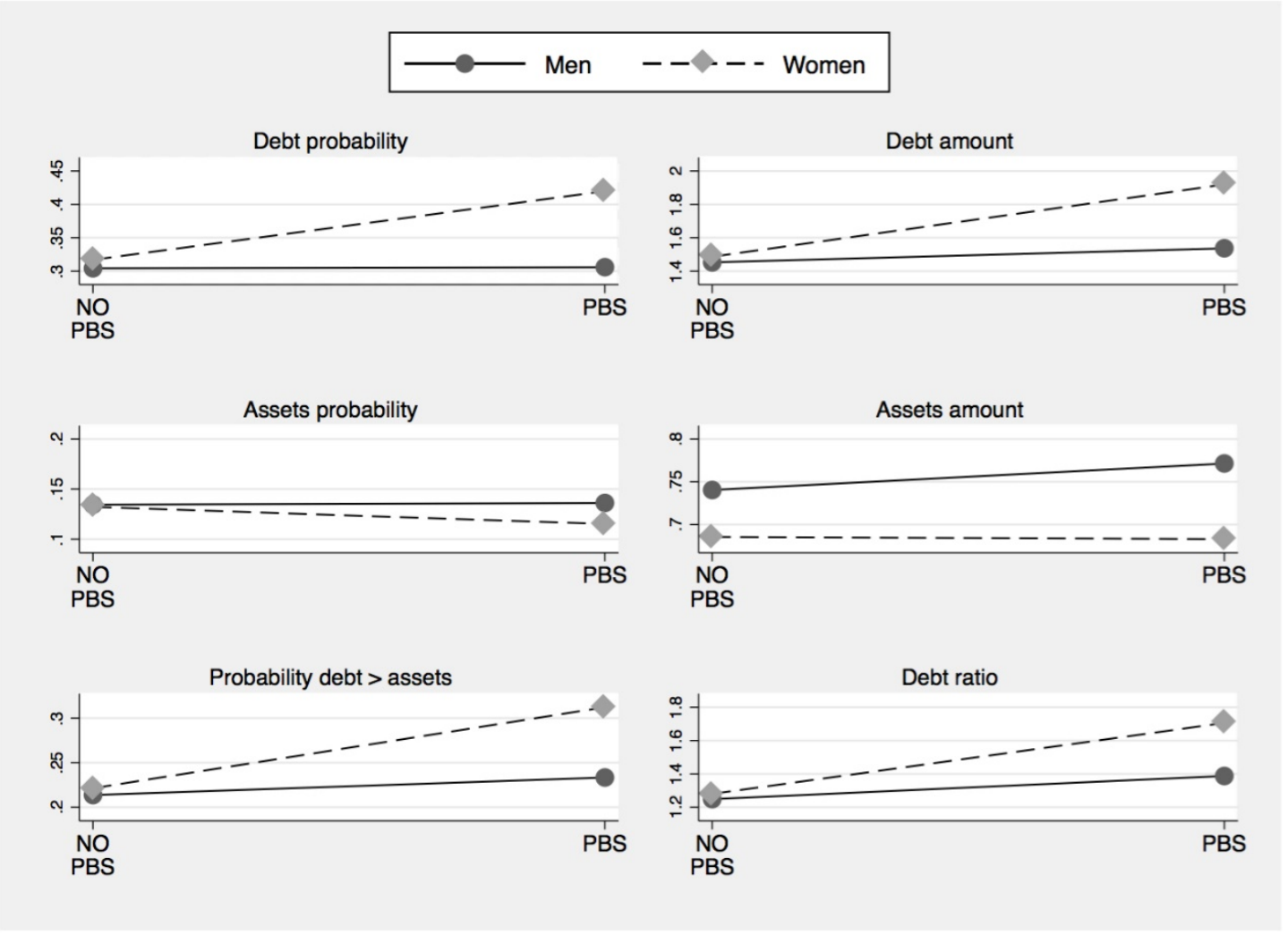

Note: Regressors constant at their means. 
All in all, the steepness of the lines suggests significant differences in the effect of the PBS on men and women. Table 5 estimates the slopes for each line. This is the effect of receiving PBS on debt and assets (probability and amount) while keeping the remaining regressors constant at their means. The effect on women who received or did not receive PBS is very steep and statistically significant in the case of debt and debt ratio (indicating a weaker financial position) and not significant for assets. No effects are significant for men.

Table 5. Contrasts of marginal linear predictions: Differences between those who received the PBS and those who did not

\begin{tabular}{lcccccc}
\hline & $\begin{array}{c}\text { Debt } \\
\text { probability }\end{array}$ & Debt amount & $\begin{array}{c}\text { Assets } \\
\text { probability }\end{array}$ & $\begin{array}{c}\text { Assets } \\
\text { amount }\end{array}$ & $\begin{array}{c}\text { Probability } \\
\text { debt }>\text { assets }\end{array}$ & $\begin{array}{c}\text { Debt ratio } \\
\text { Ln(Debt } \\
\text { ratio) }\end{array}$ \\
\hline Men & 0.005 & 0.084 & 0.008 & 0.031 & 0.066 & 0.139 \\
Women & $(0.161)$ & $(0.232)$ & $(0.182)$ & $(0.158)$ & $(0.173)$ & $(0.226)$ \\
& $0.274^{* *}$ & $0.433^{* *}$ & -0.084 & -0.003 & $0.278^{* *}$ & $0.426^{* *}$ \\
& $(0.122)$ & $(0.192)$ & $(0.161)$ & $(0.139)$ & $(0.134)$ & $(0.185)$ \\
\hline
\end{tabular}

Note: Regressors constant at their means. Standard errors in parentheses;

$* * * \mathrm{p}<0.01, * * \mathrm{p}<0.05,{ }^{*} \mathrm{p}<0.1$

We conclude that receiving PBS has different effects on the financial behavior of men and women: women increased their debt and debt ratio significantly more. The consequences in terms of well-being may be significant, since consumption of basic goods and medical treatment may be affected, as well as psychological well-being and the ability to cope with unexpected expenses.

Since the pension reform targets the low-income elderly population, our results suggest that poor elderly women are a particularly vulnerable group. To understand the larger increase in the debt of poor elderly women, we should appreciate that PBS represents a radical change in their economical situation. Financial institutions impose more obstacles on women in accessing credit (Gideon, 2006). In addition, women face higher transaction costs due to their significant domestic workload and social restrictions, which limit their mobility and ability to handle the costs of a loan application (Zúñiga Eaglehurst, 2004). Obtaining the PBS gives them solvency and reduces these transaction costs, leading women to request more credits. Therefore, this type of pension reform can be seen as an instrument for developing the financial inclusion of women, promoting their access to credit. However, at the same time, excessive indebtedness has many potential dangers and these dangers are more serious 
in their case, since various studies of developed and developing countries show that women have lower levels of financial literacy than men (Lusardi and Mitchell, 2008; Bucher-Koenen et al., 2014; Mejía and Rodríguez, 2016). Pension reforms are a good opportunity to introduce financial literacy programs and develop financial products that take into account the specific needs of women.

\section{Conclusions}

We use Chilean data from a large representative survey called Encuesta de Protección Social to investigate whether the increase in the income stream resulting from the 2008 pension reform affects participation in the debt and asset markets. We also explore the effect of the Chilean pension reform on financial outcomes separately by gender. Exploring these issues may give a fuller view of the effectiveness of the policy.

We found that those who had received a basic pension increased their debt. Significantly, they increased debt proportionally more than assets. One explanation could be that access to the financial market for the treatment group was initially low (they were partially excluded), and increased with the reform. As a result, individuals acquired more financial credibility and used the PBS as collateral to acquire more debt, rather than using it to finance new investments. Our findings also reveal that women increased their debt and debt ratio significantly more than men, leading to a weaker financial position. This result has important consequences in terms of social well-being. As poor women are a particularly vulnerable group in Chile, this may help to perpetuate inequality.

Our results indicate both positive and negative impacts of the reform on individuals. On the one hand, higher household borrowing could be an important source of economic efficiency, increasing investment opportunities and, consequently, enhancing macro-financial stability. Financial inclusion has become a topic of increasing importance for policy makers, given its critical role in reducing poverty and fostering development (World Bank, 2014; Clifton et al., 2017; Kara and Molyneux, 2017). In this sense, the PBS can play an important role as an economic instrument to promote financial inclusion by increasing household access to consumer credit with positive consequences on social welfare. Thus, positive impacts relate to the ability to purchase goods, and notably access to financial instruments generally targeted on 
wealthy consumers. Providing poor people with new financial instruments helps them to deal with potential income setbacks and reduces their financial vulnerability.

Negative impacts include problems of debt sustainability, as the use of these new financial instruments increases the risk of insolvency. Indeed, long-term excessive private debt exposes households to financial risks and potential economic setbacks that can lower their spending, with a negative impact on the growth rate of the country (Reinhart and Rogoff, 2010). This is even more significant in emerging market economies, where debt securities have only recently been introduced (Hattori and Takáts, 2015). Financial vulnerability raises concerns about the debt sustainability of the poorest households in these economies. It also has important implications in terms of welfare policies, since the consumption of basic goods and medical treatment, the ability to cope with unexpected expenses and psychological well-being may all be affected. In this regard, public interventions focusing on financial education, building trust in financial institutions, providing adequate formal savings products and credit instruments, and stimulating healthy savings habits can foster financial inclusion and generate benefits for the society as a whole (Cavallo and Serebrisky, 2016). Emphasis is also placed on the growing complexity of new financial instruments. Indeed, the lack of proper financial knowledge and decision-making skills prevents people from the availability of new financial services, possibly increasing their exposure to economic and political downturns. Further studies are needed in order to conclude which of the two effects is more significant.

This paper has two main limitations. First, due to the lack of data after 2009 and the limited amount of information available before 2006, we are unable to completely test the parallel trend assumption implicit in our diff-in-diff methodology. However, we believe that our approach, which constructs a control group made of individuals potentially eligible for FPS, compares groups of people with similar characteristics before the policy change took place. Second, we do not have the original FPS scores for most of the households, obliging us to make some assumptions. However, our results seem robust to the alternative checks we carried out (predictions obtained through regressions, principal component analysis and self-declarations in the survey). Moreover, we are aware that the consequences of this kind of reform sometimes take a long time to become manifest. Hence, it would be useful for future research to assess the effects of the reform in later periods. 


\section{Policy highgligts}

- Results contribute to raise concern about side effects of the Chilean pension reform

- Results also make visible gender imbalances in decision-making

- Pension reforms constitute a good opportunity to introduce financial literacy programs

- The outcomes call for financial products that consider the specific needs of women 


\section{References}

Altiparmakov, N., Nedeljković, M., 2018. Does pension privatization increase economic growth? Evidence from Latin America and Eastern Europe. Journal of Pension Economics and Finance, 17(01), 46-84.

Arza C., 2008. Pension reform in Latin America: Distributional principles, inequalities and alternative policy options, Journal of Latin American Studies, 40(1), 1-28.

Arza C., 2012. Pension reform and gender equality in Latin America. UNRISD Research Paper 2012-2.

Attanasio O., Meghir C., Otero A., 2011. Formal labor market and pension wealth: Evaluating the 2008 Chilean Pension Reform. University College London, mimeo.

Barrientos A., 1998. Pension reform, personal pensions and gender differences in pension coverage. World Development, 26(1), 125-137.

Barrientos A., 2006. Poverty reduction: The missing piece of pension reform in Latin America, Social Policy \& Administration, 40(4), 369-384.

Barrientos, A., Lloyd-Sherlock, P., 2003. Non-contributory pensions and poverty prevention: A comparative study of Brazil and South Africa, Manchester: IDPM and HelpAge International.

Behrman J.R., Calderon M.C., Mitchell O., Vasquez J., Bravo D., 2011. First-round impacts of the 2008 Chilean pension system reform. PARC Working Paper Series. 33.

Borzutzky, S., 2019. You win some, you lose some: Pension reform in Bachelet's first and second administrations. Journal of Politics in Latin America, July 2019, 1-27.

Brooks, S.M., 2007. Globalization and pension reform in Latin America, Latin American Politics and Society, 49(4), 31-62.

Bucher-Koenen, T., Lusardi, A., Alessie, R., Van Rooij, M., 2014. How financially literate are women? An overview and new insights (No. 201419). Munich Center for the Economics of Aging (MEA) at the Max Planck Institute for Social Law and Social Policy.

Case, A., Deaton A., 1998. Large cash transfers to the elderly in South Africa, The Economic Journal, 108, 1330-1361.

Cavallo, E., Serebrisky, T. (eds.), 2016. Saving for Development: How Latin America and the Caribbean Can Save More and Better. Springer.

Cerda R.A., 2008. Social security and wealth accumulation in developing economies: Evidence from the 1981 Chilean reform. World Development, 36(10), 2029-2044. 
Clifton, J.; Fernández-Gutiérrez, M. and García-Olalla, M. (2017). Including vulnerable groups in financial services: insights from consumer satisfaction. Journal of Economic Policy Reform, vol. 20(3), 214-237.Deere C.D., Catanzarite Z.B. (2017). Who borrows to accumulate assets? Class, gender and indebtedness in Ecuador's credit market. CEPAL Review, 122, 107-126.

Encina J., 2013. Pension reform in Chile: A difference in difference matching estimation. Estudios de Economía, 40(1), 81-95.

Engel E.M.R.A, Galetovic A., Raddatz C.E. 1999. Taxes and income distribution in Chile: Some unpleasant redistributive arithmetic. Journal of Development Economics, 59(1), 155-192.

Gideon, J., 2006. Accessing economic and social rights under neoliberalism: gender and rights in Chile. Third World Quarterly, Vol. 27, No. 7, pp 1269 - 1283.

Hattori M., Takáts E., 2015. The role of debt securities markets. BIS Paper 83c.

Herrera R., Larrañaga O., Telias A., 2010. La ficha de protección social. PNUD Documento de Trabajo, Agosto 2010.

Kara, A., Molyneux, P., 2017. Household access to mortgages in the UK. Journal of Financial Services Research, 52(3), 253-275.

Lopez Garcia, I., 2015. Human capital and labor informality in Chile: A life-cycle approach. Working Papers WR-1087, RAND Corporation. DOI: 10.7249/WR1087

López, R., Miller, S. J., 2008. Chile: The unbearable burden of inequality. World Development, 36(12), 2679-2695.

Lusardi, A., Mitchell, O.S., 2008. Planning and financial literacy: How do women fare?. American Economic Review, 98(2), pp.413-17.

Mejía, D., Rodríguez, G., 2016. N²3. Determinantes socioeconómicos de la educación financiera. Evidencia para Bolivia, Colombia, Ecuador y Perú.

Mesa-Lago C., 2002. Myth and reality of pension reform: The Latin American evidence. World Development, 30(8), 1309-1321.

Mesa-Lago, C., 2014. Reversing pension privatization: The experience of Argentina, Bolivia, Chile and Hungary, ILO Working Papers 994848943402676, International Labour Organization.

Mesa-Lago, C., and Bertranou, F., 2016. Pension reforms in Chile and social security principles, 1981-2015. International Social Security Review, 69(1), 25-45.

Morandè F.G.., 1998. Savings in Chile. What went right?. Journal of Development Economics, 57(1), 201-228. 
OECD, 2017. Pensions at a Glance 2017: OECD and G20 Indicators, OECD Publishing.

OCDE/CAF/CEPAL (2018), Perspectivas económicas de América Latina 2018: Repensando las instituciones para el desarrollo, Éditions OCDE, París.

Olivera J., 2016. Welfare, inequality and financial effects of a multi-pillar pension reform: The case of Peru. Journal of Development Studies, 52(10), 1401-1414.

Olivera, J., Zuluaga, B., 2014. The ex-ante effects of non-contributory pensions in Colombia and Peru, Journal of International Development, 26(7), 949-973.

Ramìrez, E., Ruben R., 2015. Gender systems and women's labor force participation in the salmon industry in Chiloè, Chile. World Development, 73(10), 96-104.

Reinhart, C.M., Rogoff K.S., 2010. Growth in a time of debt. American Economic Review, 100(2), 573-578.

Rofman, R., Fajnzylber, E., Herrera, G., 2008. Reforming the pension reforms: The recent initiatives and actions on pensions in Argentina and Chile. Social protection and labor discussion paper 90346, The World Bank.

Rofman, R., Oliveri, M.L., 2012. Pension coverage in Latin America: Trends and determinants, Social Protection Discussion Papers and Notes 70926, The World Bank.

Samwick A.A., 2000. Is pension reform conducive to higher saving? Review of Economics and Statistics, 82, 264-272.

Wong B., 2016. Formal sector labor supply responses to the 2008 Chilean pension system reform. University of California at San Diego, mimeo.

World Bank, 1994. Averting the old-age crisis: Policies to protect the old and promote growth. Washington, DC: Oxford University Press.

World Bank, 2014. Global financial development report, Washington DC.

Zúñiga Eaglehurst, M. 2004. Acceso al crédito de las mujeres en América Latina. Proyecto CEPAL/GTZ Políticas laborales con enfoque de género. Santiago de Chile. 